\title{
Working
}

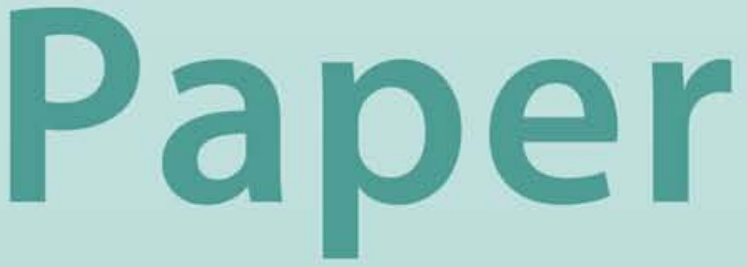


Managing Revenue Volatility in a Small Island Economy: The Case of Kiribati

Catriona Purfield 


\title{
IMF Working Paper
}

Asia and Pacific Department

\section{Managing Revenue Volatility in a Small Island Economy: The Case of Kiribati}

Prepared by Catriona Purfield ${ }^{1}$

Authorized for distribution by Jerald Schiff

August 2005

\begin{abstract}

\section{This Working Paper should not be reported as representing the views of the IMF.} The views expressed in this Working Paper are those of the author(s) and do not necessarily represent those of the IMF or IMF policy. Working Papers describe research in progress by the author(s) and are published to elicit comments and to further debate.
\end{abstract}

The formulation of fiscal policy in Kiribati faces unusual challenges. Kiribati's revenue base is among the most volatile in the world, and it possesses sizeable financial assets. Drawing on lessons from some other countries who experience high volatility in their revenues, this paper proposes a fiscal policy rule for Kiribati which is nested within a medium-term macroeconomic framework that aims to ensure the sustainable use of Kiribati's financial assets while managing the impact of extreme revenue volatility. It also discusses improvements in the institutional fiscal policy framework that could support such a framework.

JEL Classification Numbers: E62, H50, H61

Keywords: Volatiliy, fiscal policy rules, sustainability, Kiribati

Author(s) E-Mail Address: cpurfield@imf.org

\footnotetext{
${ }^{1}$ The author would like to thank Christopher Browne, Tarhan Feyzioglu, and Jerald Schiff for their helpful comments, and Vincent Moissinac for the insights provided about Mexico.
} 
Contents

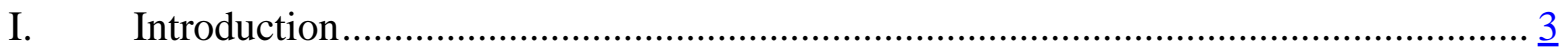

II. Just How Unique Is Kiribati’s Fiscal Environment? ........................................ 4

III. Global Experiences with Fiscal Frameworks ….............................................. $\underline{8}$

IV. Medium-Term Fiscal Framework for Kiribati ............................................... 13

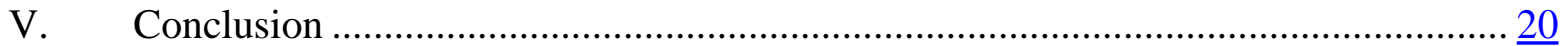

Box

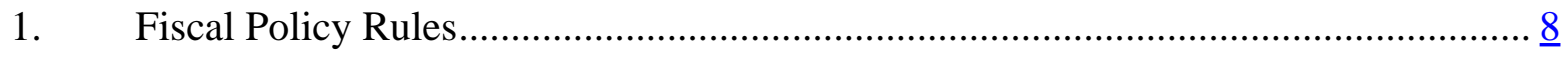

Figures

1. Revenue Volatility ................................................................................... 4

2. The Impact of Exchange Rate and International Prices on Fishing License Fees ....... $\underline{5}$

3. The Fiscal Response to Windfall Revenues..................................................... $\underline{6}$

4. Implications of Current Fiscal Policies for the RERF ......................................... 1

5. Smoothing Mechanism in Conjunction with the Medium-Term

Consolidation Strategy ............................................................................. 15

6. Medium-Term Consolidation Effort to Achieve a Sustainable Level of

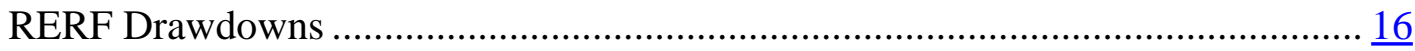

7. The Impact of Fiscal Policy Rules in Kiribati ................................................ $\frac{19}{22}$

8. Simulation of Impact of Change in Rate of Return on Fiscal Rules Framework ...... 22

Tables

1. Structure of Government Revenues, 1992-2001 ............................................. $\underline{5}$

2. RERF Simulations with No Change in Policies, 2004-2030 ................................. 7

3. Prerequisites for Fiscal Rules in Asset-Rich Economies: The Cases of Norway

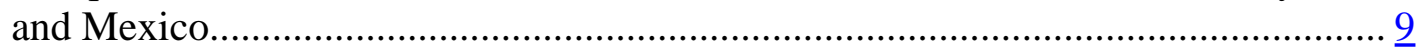

4. Macroeconomic and Fiscal Assumptions Underpinning the Medium-Term Framework............................................................................. 14

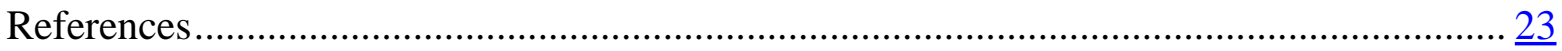




\section{INTRODUCTION}

The formulation of fiscal policy in Kiribati faces unusual challenges. Being a small island, the revenue base is highly volatile and narrow. Fishing license fees from Kiribati's rich tuna grounds and donor aid comprise the bulk of government revenues. However, these receipts fluctuate widely, reflecting exchange rate developments, weather, and donor sentiments. The domestic tax sources are limited and undeveloped, in part reflecting the absence of any significant private sector activity on the island.

Kiribati, however, is fortunate to possess a sizeable stock of financial assets, which has helped it weather its turbulent economic environment. The Revenue Equalization Reserve Fund (RERF) was established in 1956 by the British colonial government with phosphate mining royalties. When phosphate was depleted and the mine was closed in 1979 at the time of independence, the fund was worth 68 million Australian dollars (\$A). A tradition of sound fiscal management has allowed Kiribati to increase the financial assets in this fund, especially during the stockmarket boom years of the late 1990s, when the annual return to RERF peaked at 13 percent per annum and budget drawings from the fund were limited. By the end of 2000, the fund was worth \$A 658 million, approximately eight times GDP.

Starting in 2001, the government began drawing heavily from the RERF, and the fiscal situation deteriorated. In 2001, budget financing from the RERF rose sharply to $13 \frac{1}{2}$ percentage points of GDP, while the rate of return to the RERF turned negative. By 2004, drawings had doubled to 25 percentage points of GDP. The persistent drawings and average negative rate of return over the 2001-04 period resulted in a decline in the real per capita value of the fund (in 1996 prices) to \$A 5,502 from a peak of just over \$A 7,000 in 2000. This decline occurred despite the parliamentary decision in 1996 to maintain in principle the RERF's expected real per capita value as constant for future generations.

The key challenge for fiscal policy formulation is to ensure medium-term fiscal sustainability that preserves RERF assets, while handling the spillover of revenue volatility into the budget. Experiences of other countries suggest that (i) medium-term fiscal frameworks, comprising fiscal rules that take into account both short-run volatility and long-run sustainability, and (ii) greater transparency in the structure and functions of budget institutions can help Kiribati achieve this objective. Such frameworks help check political incentives for policymakers to pursue shortsighted policies.

The remainder of the paper is organized as follows. Section II underscores the challenges facing fiscal policy formulation in Kiribati by reviewing how the small and volatile nature of its economy affects fiscal performance. Section III reviews how fiscal rules can help induce fiscal discipline by assessing the rules applied in two resource-rich economies, Norway and Mexico. Section IV outlines the main pillars of a medium-term fiscal framework for Kiribati that aims to restore polices to a sustainable path while at the same time reducing the impact of revenue volatility on the budget. Section VI concludes. 


\section{JUST HOW UNIQUE IS KIRIBATI’s FISCAL ENVIRONMENT?}

Kiribati's situation can be judged along two broad dimensions. First, does the very small, open nature of its economy induce greater volatility into fiscal policy than is typical for other economies? And second, has the availability of RERF assets facilitated a loosening of fiscal discipline? The answer to both these questions is a qualified "yes".

The government's revenue base is one of the most volatile in the world. On a year-to-year basis, the growth in government revenues in Kiribati fluctuates by about 25 percentage points of GDP. To put this in perspective, revenue growth in Kiribati is about three times as volatile as that in Africa, six times more volatile than in Asia and the Middle East, and eight times more volatile than in industrialized economies (Figure 1). This volatility is also much more pronounced than that experienced by other islands in the region, with the

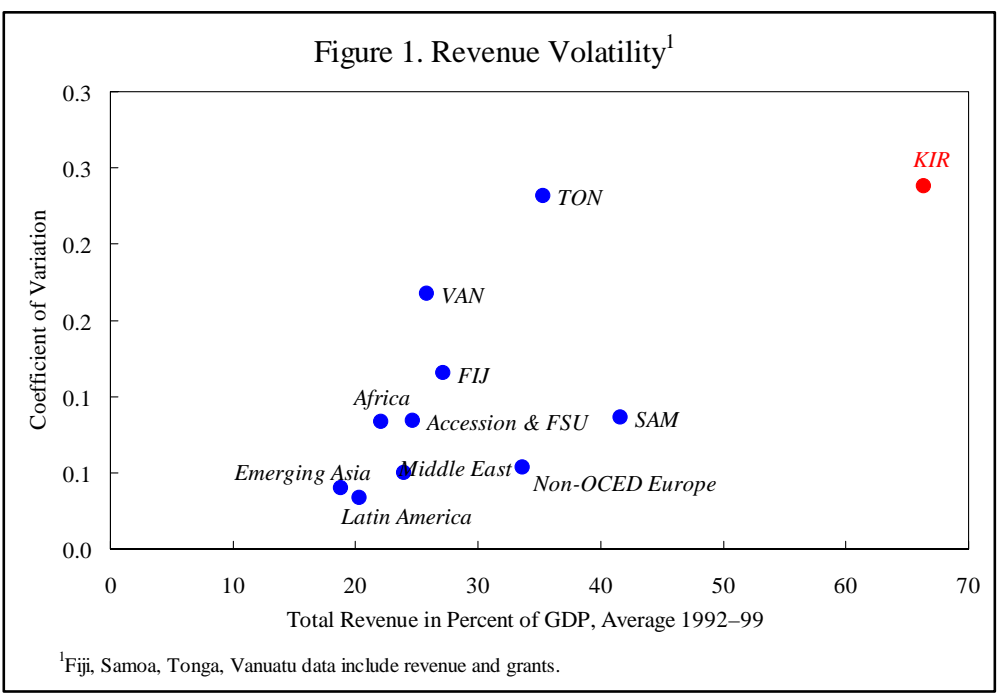
exception of Tonga where volatility in revenue growth is almost on par.

The volatility in revenue primarily reflects a narrow tax base and an undiversified economy. By international standards, Kiribati's tax base is highly dependent on nontax and grant revenues (Table 1). Fishing license fees and donor grants comprise the bulk of receipts. They account for two-thirds of the total volatility in revenues, with shocks to GDP growth accounting for the remainder. Fishing license receipts are typically denominated in foreign currencies and are subject to vagaries in weather, which drive movements of fish stocks (typically over an eight- to ten-year cycle), and international prices (Figure 2). For example, in 2004 about two-thirds of the \$A 9.2 million (61/2 percent of GDP) decline in fishing license fees reflected currency movements. Only one-third reflected the seasonal fall in fish catch. The government has made some progress in reducing the volatility in fishing fees by entering into long-term contracts that have helped reduce overall volatility in revenue growth to 20 percentage points of GDP between 2000 and 2004. 


\begin{tabular}{|c|c|c|c|c|c|c|c|}
\hline \multicolumn{8}{|c|}{ Table 1. Structure of Government Revenues, 1992-2001 } \\
\hline & Africa & Asia & Europe & $\begin{array}{c}\text { EU Accession/ } \\
\text { Former Soviet Union }\end{array}$ & $\begin{array}{l}\text { Middle } \\
\text { Eastern }\end{array}$ & Americas & Kiribati \\
\hline & \multicolumn{7}{|c|}{ (percent of GDP) } \\
\hline Total Revenue & 21.5 & 18.7 & 34.1 & 24.1 & 24.7 & 20.3 & 106.0 \\
\hline Tax revenue & 17.1 & 13.3 & 29.6 & 21.8 & 14.1 & 16.9 & 24.6 \\
\hline Direct taxes & 4.8 & 4.3 & 6.6 & 3.5 & 5.0 & 3.9 & 8.7 \\
\hline Indirect taxes & 4.8 & 5.0 & 11.0 & 9.7 & 3.8 & 6.6 & 16.2 \\
\hline \multirow[t]{2}{*}{ Nontax and grant revenue } & 4.4 & 5.4 & 4.5 & 2.3 & 10.6 & 3.3 & 81.4 \\
\hline & \multicolumn{7}{|c|}{ (percent of total) } \\
\hline Total Revenue & 100.0 & 100.0 & 100.0 & 100.0 & 100.0 & 100.0 & 100.0 \\
\hline Tax revenue & 79.4 & 71.1 & 86.8 & 90.5 & 57.1 & 83.5 & 23.2 \\
\hline Direct taxes & 22.2 & 22.9 & 19.5 & 14.3 & 20.2 & 19.0 & 8.2 \\
\hline Indirect taxes & 22.4 & 26.9 & 32.1 & 40.3 & 15.3 & 32.7 & 15.3 \\
\hline Nontax and grant revenue & 20.6 & 28.9 & 13.2 & 9.5 & 42.9 & 16.5 & 76.8 \\
\hline
\end{tabular}

Figure 2. The Impact of Exchange Rate and International Prices on Fishing License Fees ${ }^{1}$
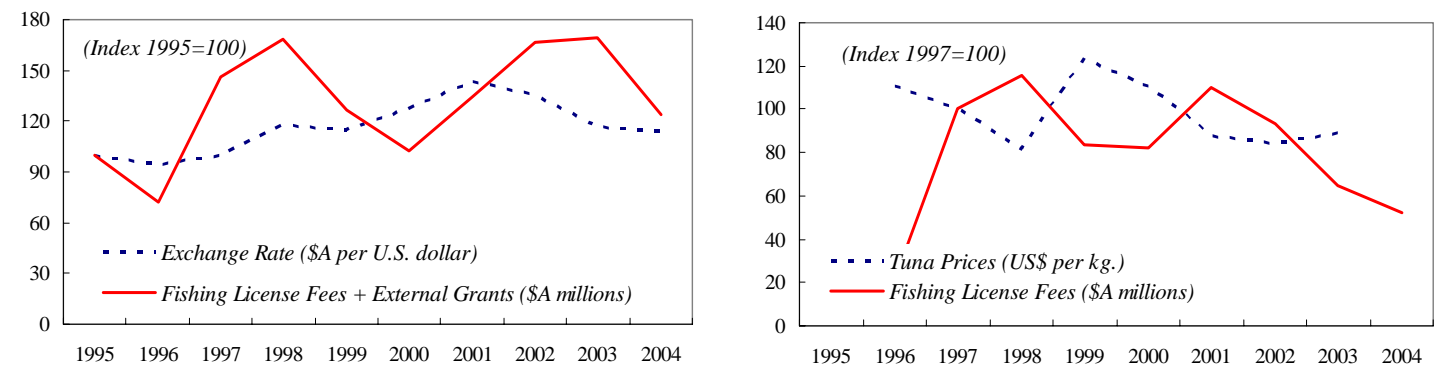

Source: IMF staff calculations.

${ }^{1}$ All series are in shown as indices.

Most countries find it difficult to build up public savings in the presence of large assets. This tendency is particularly pronounced in nonindustrialized economies where high volatility in tax bases (compared to industrial economies) and weak political institutions foster shortsighted policies by allowing policymakers unchecked discretion (Talvi and Végh, 2000). In asset-rich countries, this problem is exacerbated by the volatility in commodity prices which generates large but temporary windfall receipts (see Davis, Ossowski, and Fedelino, 2003). Many countries have experimented with savings or stabilization funds to insulate their economies from commodity price volatility. However, in the majority of cases, windfalls and assets tend to be spent. Nauru, another phosphate-rich island, offers an example. At the peak of its wealth Nauru had financial assets worth \$A 1.3 billion, or \$A 3,800 per capita. However, these assets have been virtually eliminated due to fiscal mismanagement. 
Kiribati, however, has had a tradition of conservative fiscal management and has built up substantial savings. On average, it has successfully controlled spending pressures in times of plenty. $^{2}$ Figure 3 identifies four periods between 1990 and 2004 when government receipts exceeded the average revenue-to-GDP ratio of that period. The windfall revenues were substantial, averaging 13.2 percentage points of GDP, and for the most part arose in periods of bumper fishing catches when El Niña conditions prevailed in the Pacific (for example, in 1997-1998 and in 2001-2003). While the government's behavior varied greatly in each episode, on average across these four episodes it saved about 80 percent of the windfall revenues.

The buildup of these savings occurred despite the lack of any explicit rule to safeguard the value

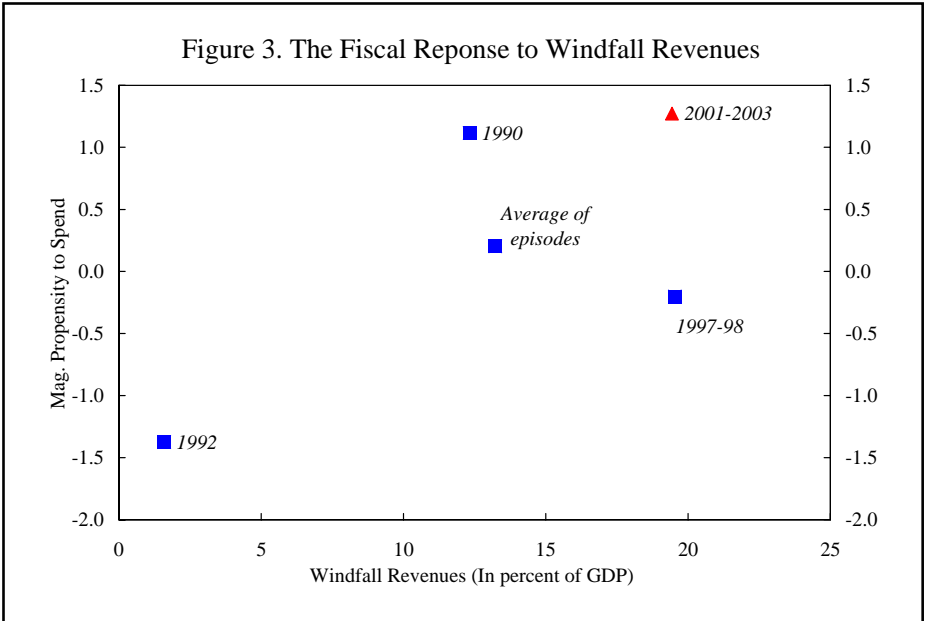
of the RERF-fiscal policy is not subject to any explicit rules, and there is no dedicated legislation governing the RERF. The 1979 Public Finance Act, Kiribati's budget law, set outs general principles to guide government investments, including those of the RERF. There is no explicit rule governing the size of drawings for budget financing, and the government does not need parliamentary approval to increase drawings above budgeted levels. However, in 1996 parliament agreed in principle to hold the RERF's expected real per capita value constant for future generations. The use of the Australian dollar as domestic currency and the absence of a domestic debt market preclude other sources of domestic financing.

The strong performance of global equity markets helped boost the value of the RERF between 1996 and 2000, when the average rate of return on RERF assets averaged a record 13 percent per annum, buoyed by the information-technology-related boom in international stock markets. The government could have drawn down, on average, about 57 percent of GDP each year from the RERF over this 5-year period while observing the constant per capita wealth principle. However, fiscal policy was on average more conservative. While the constant real wealth principle was not strictly followed each year, average drawdowns over this 5-year period were limited to 5.6 percent of GDP per annum, allowing the government to effect 55 percent real increase in value of RERF assets per citizen.

\footnotetext{
${ }^{2}$ The correlation between GDP growth and the fiscal deficit in Kiribati is significantly negative $(-0.44)$ signaling that periods of good growth are associated with lower fiscal deficits.
} 
Starting in 2001, budget expenditures began to rise more quickly than revenues, and the growing deficit required large drawings from the RERF. In 2001, expenditures rose sharply, and budget financing from the RERF rose to 13.5 percentage points of GDP despite nearrecord levels of revenues. Although the constant per capita wealth principle called for budget surpluses of about 40 percent of GDP as revenues continued their climb to new records through 2003, spending continued to rise faster than revenues. When revenues returned to trend levels in 2004, it was difficult to adjust expenditures. The fiscal deficit ballooned to 41.3 percent of GDP, requiring a record drawdown of 24.5 percent of GDP from the RERF to finance the deficit. Over the same period, the stock market corrections caused the rate of return on the RERF to turn sharply negative. With persistent drawings and average negative rates of returns, the real per capita value of the fund (in 1996 prices) declined to \$A 5,502 from its peak of \$A 7,081 in 2000.

If current policies continue, the RERF risks depletion. To determine the implications of current policies for RERF sustainability, we assume growth continues to stagnate, population growth continues at current levels, the return on RERF investments matches the long-term yield on Australian government bonds, and in view of Kiribati's use of the Australian dollar as its domestic currency, inflation converges to the Australian level of $21 / 2$ percent (Table 2 ). The fiscal deficit is projected to rise over the medium-term reflecting the nonbuoyant nature of Kiribati's main revenues and pressure to keep

Table 2. RERF Simulations with No Change in Policies, 2004-2030 (percent, unless otherwise indicated)

\begin{tabular}{lc}
\hline & \\
\hline Real GDP growth & 0.7 \\
Population growth & 1.7 \\
Nominal rate of return $^{1}$ & 5.6 \\
RERF drawdown (percent of GDP) & -25.6 \\
\hline${ }^{1}$ Yield on long-term Australian bonds.
\end{tabular}

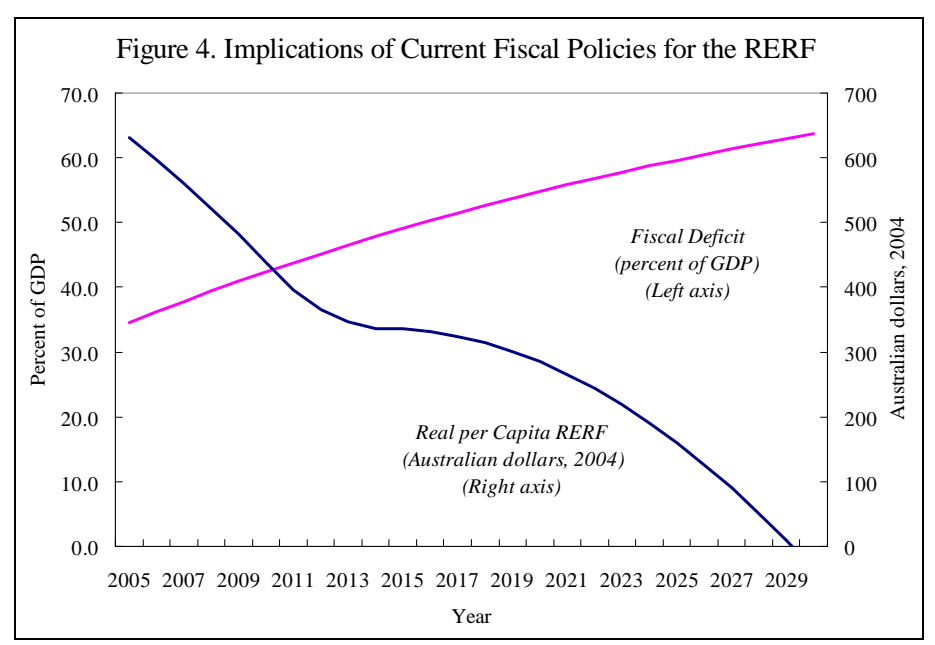
spending high. Government revenues are forecast to fall as a share of GDP, as fishing license fees and government grants remain constant in nominal terms at their 10-year average. On the other hand, population pressures, owing in part to the lack of an emigration tradition, force spending to grow in sync with nominal GDP so that budget outlays stay constant as a share of GDP. The rising fiscal deficit that results requires increasing drawdowns from the RERF. This simulation shows the value of the RERF will be halved in 13 years and that the RERF will be depleted in 24 years (Figure 4). 


\section{GLOBAL EXPERIENCES WITH FISCAL FRAMEWORKS}

Many countries have adopted rules-based, medium-term frameworks to address the deficit bias in fiscal policies. These rules take many forms, but generally comprise permanent restrictions on deficits, borrowing, and expenditures (Box 1). However, cross-country experiences with such frameworks have been mixed, particularly in resource-rich economies. Successful frameworks are shown to be those that are credible and enforceable. In resource-rich economies, credibility requires safeguarding sustainability while handling substantial revenue volatility. Enforceability requires that policymakers be punished for poor policy choices.

The experiences of Norway and Mexico can help identify key ingredients for successful rules-based, medium-term frameworks. Norway and Mexico, two resource-rich countries who, like Kiribati, have large financial assets (Norway) and/or highly volatile revenues (Mexico and Norway) adopted fiscal frameworks with differing degrees of success. Their contrasting experiences show that sound numerical fiscal targets that promote sustainability and facilitate monitoring, while important, are rarely sufficient to ensure sustainable policies in practice. Rules-based fiscal frameworks also need to be backed by a high degree of political ownership and sound policies that are firmly grounded in realistic medium-term budget forecasts. Enforceability also requires simplicity

Box 1. Fiscal Policy Rules ${ }^{1}$

Balanced Budget or Deficit Rules

- Balance between overall revenue and expenditure, or a limit on government deficit as a proportion of GDP-for example, EU, Canada, Italy, Germany, and Spain.

- Balance between structural (or cyclically adjusted) revenue and expenditure; or a limit on the structural balance as a proportion of GDP - for example, Switzerland and Chile.

- Balance between current revenue and current expenditure so that borrowing is permitted only to finance capital expenditure-for example, India and the United Kingdom.

\section{Borrowing Rules}

- Prohibition of domestic government borrowing - for example, Indonesia.

- Prohibition or limit on central bank borrowing-for example, EU, Argentina, Chile, Peru, Hungary, and the CFA Zone.

\section{Debt or Reserve Rules}

- Limit on the stock of gross (or the net) debt as a proportion of GDP-for example, EU.

- Target the stock of reserves of extra budgetary contingency funds (social security) as a proportion of annual benefit payments.

${ }^{1}$ Kopits and Symansky (1998). and transparency in implementation so that the public can hold policymakers accountable for their decisions and provide incentives for prudent fiscal decisions. Table 3 summarizes the findings. 
Table 3. Prerequisites for Fiscal Rules in Asset-Rich Economies: The Cases of Norway and Mexico

\begin{tabular}{|c|c|c|}
\hline Prerequisites & Norway: State Petroleum Fund (SPF) & Mexico: Oil Stabilization Fund (OSF) \\
\hline Sound numerical rules & $\begin{array}{l}\text { Non-oil budget surplus rule ensures sustainability and stabilization. } \\
\text { Cyclically adjusted non-oil deficit cannot exceed the real return on the capital of } \\
\text { the petroleum fund. An escape clause allows abrupt changes in the target deficit } \\
\text { (e.g., a fall in the stock value of SPF assets) to be smoothed out over a number of } \\
\text { years. } \\
\text { Forward-looking } 50 \text {-year fiscal projections are prepared to illustrate the rule. }\end{array}$ & $\begin{array}{l}\text { Oil reference price rule stabilizes the impact of oil price fluctuations on the budget. } \\
\text { Originally, drawdowns were permitted of up to } 50 \text { percent of fund assets if the oil price } \\
\text { was below the certain threshold. However, this rule has been changed repeatedly, and } \\
\text { currently, up to } 50 \text { percent of surplus oil receipts can be spent. } \\
\text { No permanent rule guides fiscal policy and there are no medium-term fiscal estimates. } \\
\text { However, an explicit annual net indebtedness target has been adopted by parliament. In } \\
\text { addition. the constitution only permits borrowing to finance investment. }\end{array}$ \\
\hline Strong ownership & $\begin{array}{l}\text { SPF and drawdown of SPF assets are incorporated into the annual budget } \\
\text { process. } \\
\text { Parliamentary approval is required for the use of oil funds to finance the non-oil } \\
\text { deficit. }\end{array}$ & OSF drawdowns are transferred to the budget. \\
\hline Good Governance & $\begin{array}{l}\text { Frequent and public reports on SPF performance } \\
\text { Benchmarking of SPF performance } \\
\text { Independent assessment of SPF performance }\end{array}$ & No formal reporting on the OSF \\
\hline $\begin{array}{l}\text { Reporting and } \\
\text { statistical standards }\end{array}$ & $\begin{array}{l}\text { Comprehensive fiscal accounts cover all elements of the federal government and } \\
\text { transfers relating to the SPF. } \\
\text { Macroeconomic assumptions underpinning annual budget and 50-year } \\
\text { projections are published and explained. } \\
\text { Sound budget analysis: the budget clearly shows the oil and non-oil components } \\
\text { of the budget balance. } \\
\text { Monthly reports are issued on budget implementation. } \\
\text { Accounts are compiled on an accrual basis. }\end{array}$ & $\begin{array}{l}\text { OSF is excluded from deficit measures, except for transfers in and out. } \\
\text { Macro forecasts for the annual budget are published, but no information is given about } \\
\text { the underlying assumptions. } \\
\text { Oil revenue is included in overall revenue, and no distinction is made between the oil and } \\
\text { non-oil balance. } \\
\text { Monthly and quarterly reports are issued on budget implementation. } \\
\text { Accounts are compiled on an cash basis. }\end{array}$ \\
\hline
\end{tabular}




\section{Norway}

Norway possesses substantial oil and financial assets. Norway's financial assets from the sale of oil are expected to reach 120 percent of GDP by 2010 and 160-170 percent of GDP by 2030 (Skancke, 2003). As for Kiribati, Norway's oil-related tax revenues are extremely volatile, but its non-oil revenues are relatively stable and robust. Norway also faces sizeable spending pressures from the rapid aging of its population.

Norway successfully established a State Petroleum Fund (SPF) to reconcile the need to ensure long-run fiscal sustainability with the need for fiscal stabilization. The SPF was first established by parliament in 1990 to create transparency in the use of Norway's oil revenue. Drawdowns from the fund are governed by long-run sustainability considerations and are approved by parliament in the annual budget (Bjerkholt and Niculescu, 2004). The first transfers were made to the SPF in 1996 after the 1990-1995 recession ended. By 2001, Norway, like Kiribati, had built up sizeable financial assets in the SPF, worth 45 percent of GDP. These are invested externally. Several factors contributed to this outcome.

\section{Sound Numerical Targets}

- $\quad$ Norway's numerical rule ensures fiscal sustainability, insulates the budget from oil price volatility, and is flexible to macroeconomic shocks. Fiscal policy is subject to a well-defined rule that limits the SPF drawdowns for the cyclically adjusted non-oil deficit to the realized real rate of return on assets in the SPF. Linking SPF drawdowns to the realized rate of return on its assets enables Norway to preserve its oil wealth for future generations by capping drawdowns to a sustainable level. The rule also helps to decouple expenditures from oil price volatility. Adjusting the fiscal position for cyclical conditions promotes budget stability by requiring the government to build savings in upswings to help smooth revenue fluctuations during downturns. By focusing on the non-oil deficit, the rule highlights the tradeoff between the need to run an overall budget surplus for transfer to the SPF and using oil revenues to finance non-oil deficits. While there are no formal rules constraining the size of the non-oil deficit, this has not proven to be a problem because Norway has a tradition of sound fiscal management.

- $\quad$ The operation of the rule is greatly facilitated by the preparation of long-range fiscal projections covering a 50-year period. These forecasts are a useful tool in generating the political consensus needed to build substantial savings. They give a long-term perspective to the budget process by switching the policy emphasis away from annual targets. By clearly illustrating the timeline for the eventual depletion of oil receipts and rising spending pressures, the long-range forecasts can help dissipate political pressure for higher spending, especially in times of high revenue. 


\section{High Degree of Ownership}

- $\quad$ Active involvement by parliament in decisions about the use of the SPF helps generate the political consensus to support the framework. Transfers to and from the SPF are fully incorporated into the annual budget process, allowing parliament to vet whether the non-oil balance is in compliance with the rule. Parliament is also required to approve the use of oil funds to finance the non-oil deficit.

\section{High Standards of Governance}

- $\quad$ Transparency is key to building a political and public consensus around the accumulation of sizeable financial assets. The public is well informed about how the money is invested and how these investments perform. Detailed reports on the SPF's performance, including figures on the rate of return, benchmark returns, and management costs, are made public and are available on the web. An independent company assesses deviations in the SPF's performance from industry benchmarks, and these reports are also available on the internet.

\section{Sound Reporting and Statistical Standards}

- $\quad$ Surveillance of the fiscal rule relies on high-quality, reliable, and timely fiscal statistics. Allowing the public and financial markets to better assess performance is a key element for reputation-based enforcement mechanism. In the budget formulation process, the macroeconomic assumptions and policies underpinning the annual and medium-term fiscal calculations are published and explained. This helps check any tendency for policymakers to overstate growth in order to show they are in compliance, ex ante, with the rules. Timely monthly data on budget implementation are available. Fiscal accounts are comprehensive, and the oil and non-oil components of the budget balance are isolated.

\section{Mexico}

Mexico's budget, like Kiribati's, is subject to highly volatile revenue sources. Government revenues are dominated by volatile nontax receipts from the oil sector, and its non-oil tax base is relatively narrow. On the expenditure side, Mexico faces sizeable unmet investment needs including in the social sectors and the state-owned energy sector. In contrast to Norway, Mexico's fiscal rules focus on managing the potential impact of revenue volatility on the economy rather than on promoting long-run sustainability in the use of oil resources. This is done through two tools: annual automatic fiscal "adjusters" that guide the use of oil revenues, and an Oil Stabilization Fund (OSF) which receives fiscal savings when oil prices are high. However in practice, Mexico has saved little in times of high oil prices, and the OSF, which was established in 2000, was depleted by 2002. Little progress has been made since then in replenishing it. Various factors contributed to this outcome. 


\section{Highly Discretionary Numerical Rules}

- $\quad$ The rules underpinning Mexico's fiscal framework focus exclusively on how unexpected (i.e., in excess of budgeted) oil revenues are to be utilized. The budget law states that oil receipts in excess of the budget assumption are first to be used to offset shortfalls in non-oil revenues and/or to finance overruns in non-discretionary expenditures (for example, interest, arrears, or higher energy costs). “Adjusters” determine how any remaining excess oil revenues are to be used. These adjusters are set annually in the budget law and have been subject to numerous revisions by congress over the years. In 2003 these adjusters stated that any excess revenues should be divided between the federal government (50 percent), transfers to the OSF (25 percent), and deficit reduction (25 percent).

- $\quad$ The repeated relaxation of the adjustors allowed governments to spend temporary oil windfalls and precluded the build up of savings in the OSF. The adjusters allowed oil receipts to compensate for shortfalls in non-oil tax collections, and absent a rule to constrain the size of the non-oil deficit and/or a conservative fiscal stance, the non-oil deficit rose to 10 percent of GDP.

- $\quad$ The absence of a medium-term fiscal framework to anchor the rules and to highlight the trade-off between spending and saving to some extent facilitated these policy choices.

\section{Weak Ownership and Governance}

- $\quad$ Mexico finds it difficult to save oil revenues, either as a means to offset temporary price fluctuations or to ensure future generations benefit from the oil wealth. Notwithstanding the fact that oil prices have been uniformly higher than budgeted, little progress has been made in replenishing OSF assets. The repeated incremental revisions to the adjustors increased the amount of excess revenues that could be spent-less than 0.2 percent of GDP of excess revenue could be spent in 2000, but by 2003, half of the excess could be spent. There seems little point in having fiscal rules when they can be changed on an annual basis and are not legally binding (although written into the annual budget laws, the government retains discretion in applying the adjustors).

\section{Some Statistical Shortcomings}

- $\quad$ Transparency regarding the trend and use of oil receipts is undermined to some extent by accounting conventions. While Mexico has a good track record in producing frequent reports on budget implementation, its rules do not distinguish between the oil and non-oil components of the overall balance. This makes the trade-off between spending and saving less clear. 


\section{MEDIUM-TERM FISCAL FRAMEWORK FOR KIRIBATI}

The adverse implications of Kiribati's unsustainable and unstable policies are clear. The principle aim of a medium-term fiscal framework is to provide Kiribati with an institutional framework to address its twin challenges of attaining a sustainable fiscal position while minimizing the impact of volatility on the budget. The framework is built on three pillars.

- $\quad$ Fiscal discipline: The framework sets a numerical anchor for fiscal policy to bring the RERF drawdown to a sustainable level.

- $\quad$ Fiscal stabilization: The framework aims to restore the stabilizing properties of fiscal policy by requiring unexpected revenues to be saved in periods of good performance. This provides the government a cushion in years of poor economic performance to support a smooth path of expenditure.

- $\quad$ Enforceability: Greater transparency is needed to ensure that politicians are held accountable for implementing and complying with the framework. Sanctions could also be considered in the event that the targets in the framework are missed.

\section{Promoting Fiscal Sustainability}

To ensure fiscal discipline, the framework should be guided by a numerical rule that ensures fiscal policy is consistent with the sustainable use of RERF assets. A rule restricting financing of the budget deficit to the realized real per capita rate of return on the RERF has proven to be a successful and sound numerical anchor for fiscal policy in asset-rich countries. ${ }^{3}$ It determines a sustainable level of drawdowns consistent with holding the level of real per capita capital constant for future generations as per the following formula:

$$
d=\left(i_{t}-n_{t}\right)\left(R E R F_{t-1}\right)
$$

where $i$ is the average real rate of return on RERF assets adjusted for the average rate of population growth, $n$, and RERF is the stock of RERF assets. However, Section II showed that in Kiribati the sustainable RERF drawdown varies widely over time, particularly with changes in the rate of return on investments. ${ }^{4}$ Using longer-run values of these variables, based on the assumption that economic growth will gradually return to a long-run average of 3 percent over a five-year period, the deficit is reduced by about 5 percentage points of GDP per annum during a five-year adjustment phase (see below) and the real rate of return is aligned to rate on the long-run Australian T-Bill (Table 4). Under this scenario, it is possible to arrive at a

\footnotetext{
${ }^{3}$ It is also similar to the principle approved by Kiribati's' parliament to hold constant the “expected” real per capita return on the RERF.

${ }^{4}$ RERF assets are invested equally in fixed-income instruments and equity instruments.
} 
sustainable level of RERF drawdowns of about 5 percent of GDP. Under this system, unanticipated and temporary changes in the rate of return on the RERF portfolio relative to the assumed targeted level should be saved or accommodated. The long-run sustainable level of drawdown is also dependent on the speed with which the government adjusts its policies to restore sustainability. If it succeeds in adjusting more quickly, say over a three-year rather than a five-year horizon as is assumed here, the sustainable level of drawdown increases to 7 percent of GDP because the size of the RERF is larger.

\begin{tabular}{|c|c|c|c|c|c|c|}
\hline & \multicolumn{4}{|c|}{ Historical Data } & \multirow{2}{*}{\multicolumn{2}{|c|}{ Assumptions }} \\
\hline & \multicolumn{2}{|c|}{ Average } & \multicolumn{2}{|c|}{ Standard Deviation } & & \\
\hline & 10-year & $\overline{5 \text {-year }}$ & 10-year & $\overline{5 \text {-year }}$ & $2005-2009$ & $2010-2014$ \\
\hline & \multicolumn{6}{|c|}{ (percent) } \\
\hline \multicolumn{7}{|l|}{ Real sector } \\
\hline Real GDP growth & 3.6 & 0.4 & 4.3 & 0.9 & 1.4 & 3.0 \\
\hline CPI inflation & 2.0 & 1.9 & 2.7 & 3.0 & 2.1 & 2.5 \\
\hline Population growth rate & 1.7 & 1.4 & 0.0 & 0.0 & 1.7 & 1.7 \\
\hline & \multicolumn{6}{|c|}{ (millions of Australian dollars) } \\
\hline \multicolumn{7}{|l|}{ Fiscal sector } \\
\hline Fishing revenues & 29.0 & 34.8 & 11.7 & 9.0 & 27.3 & 28.0 \\
\hline External grants & 32.5 & 42.9 & 17.3 & 20.9 & 55.0 & 55.0 \\
\hline & \multicolumn{6}{|c|}{ (percent) } \\
\hline \multicolumn{7}{|l|}{ RERF } \\
\hline Nominal rate of return & 7.0 & 1.5 & 12.0 & 8.0 & 5.6 & 5.6 \\
\hline
\end{tabular}

\section{Promoting the Stabilizing Role of Public Finances}

The framework should also guarantee sufficient flexibility to allow fiscal policy to counteract the large volatility in Kiribati's economy while preserving fiscal discipline. In view of the high volatility in its revenue base, Kiribati needs to build up savings in good times to provide a buffer for fiscal policy in bad times so that the government can sustain its expenditures without having to resort to procyclical cuts. Such an approach would allow fiscal balances to expand and contract (breathe) around the long-run sustainable level.

A smoothing mechanism should encourage the government to build savings by running fiscal surpluses in good times. It is important that the mechanism be simple to ensure ease of monitoring. In operational terms, this requires policymakers to assess whether actual revenue collections are above or below expectations. This can be done by establishing a reasonable and simple benchmark against which to compare actual collections. The main seasonal 
component of the revenue base is fishing license fees. ${ }^{5}$ Comparing actual collections of these fees to their historical average level establishes a simple and observable benchmark. Typically, historical data suggest that a reasonable benchmark level of fiscal license fees over the duration of a full El Niña fishing cycle is about \$A 28 million per year. If, in any year, realized collections are higher than this, the government should save the surplus relative to the benchmark. In years of poor

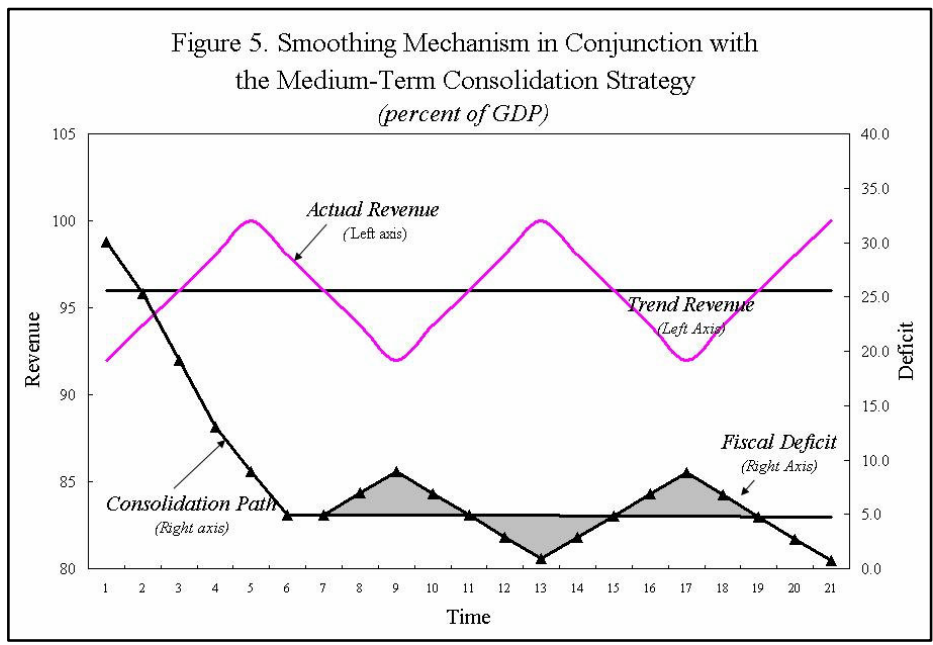
collections, the government could draw on the surpluses that it accumulated in earlier years to bring revenues to their average level (Figure 5). The mechanism would operate so that over a typical revenue cycle, the deficit would average 5 percent of GDP and expenditure would be smooth. Were such a mechanism place between 2000 and 2003, the government would have run a deficit of about 2 percent of GDP in 2001, compared to the actual deficit of 17 percent of GDP. In 2003, the deficit would have been about half the actual level recorded.

Information about the volatility in fishing license revenues can be used ex ante to set feasible bounds on the deviation in the budget balance around its long-run sustainable level. Fishing license fees, have fluctuated by 121/2 percentage points of GDP annually over the last 10 years. Recently, about two-thirds of the decline in these receipts reflected the appreciation of the domestic currency against the U.S. dollar. To ensure that fiscal policy adjusts to this structural change, the bounds for the smoothing mechanism should only take into account the volatility in fishing license fees arising from the seasonal variations in fish stocks. Over the medium term, this creates a feasible range of about 4 percentage points of GDP for the actual budget deficit to fluctuate around its long-run, RERF-compatible level of about 5 percent. This implies that at the weakest stage of a typical fishing revenue cycle, the deficit could rise to a maximum value of about 10 percent of GDP. However, at the peak of a typical cycle, Kiribati should be running a small deficit of $1 \frac{1}{2}$ percent of GDP. ${ }^{6}$

\footnotetext{
${ }^{5}$ We limit the focus to domestic revenue sources because donor inflows are primarily linked to development expenditures or off-shore purchases. The government also has signaled that it intends to strictly limit its development (capital) spending to available donor inflows.

${ }^{6}$ The range, $\mathrm{r}$, within which the deficit can fluctuate is calculated by $r=t^{a v g}(C-1)$, where $\mathrm{t}^{\mathrm{avg}}$ is taken to be the average revenue-to-GDP ratio forecast over the next 10 years (96 percent of GDP) and $\mathrm{C}$ is the deviation in revenue due to changes in fish stocks.
} 
The scope for implementing the smoothing mechanism will, at least in the initial phases of the consolidation, be limited. Until sufficient savings are accumulated to accommodate the large swings in revenue, the government will have to resist implementing the mechanism in times of poor revenue performance lest it jeopardizes the fiscal adjustment effort. The timing of implementation will depend crucially on the speed with which fiscal policy convergences to the medium-term fiscal sustainability target. A faster pace of adjustment will allow the government to build its buffer savings quicker. However, the fact that the bulk of government expenditure is on wages and capital outlays, a faster pace of expenditure adjustment than the five years envisaged under the simulation is likely to prove challenging.

\section{Ensuring Consolidation}

Kiribati's current fiscal policies are inconsistent with the constant per capita wealth rule. The overall budget deficit amounted to about 40 percent of GDP in 2004, and implementation of the constant rule would require an fiscal consolidation effort of about 35 percent of GDP. Obviously, an adjustment of this size is too large to be implemented in a short period of time. The government needs to map out an ambitious but credible consolidation strategy backed by policy measures that achieve this goal. The medium-term fiscal framework can be used to set the annual targets and policies over the consolidation period. Figure 6 shows one consolidation path where the government seeks to secure savings in government outlays of about 5 percent of GDP per annum between 2005 and 2010, through a combination of wage,

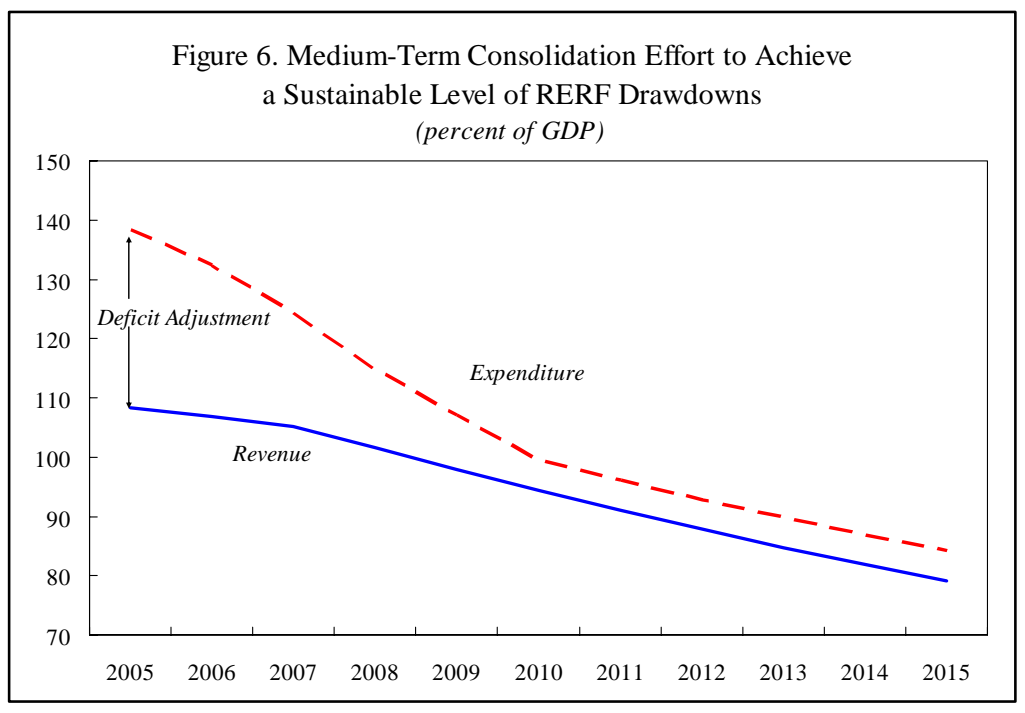
subsidy, and transfer reform and by restricting development (capital) spending to realized donor aid.

Evidence from countries that undertook large-scale adjustments suggests that although difficult, savings of this magnitude should be feasible, especially if led by expenditure restraint. Schuknecht and Tanzi (2005) find Belgium, Ireland, the Netherlands, and New Zealand reduced spending by about 131/4 percentage points of GDP from their peak levels in the mid-1980s. In Latin America, Shi (2002) finds Brazil, Mexico, and Venezuela adjusted their primary balance by between 7 and 15 percentage points of GDP over periods of one to three years. These and other authors (Alesina and Perotti, 1995, for OCED countries, Giavazzi, Jappelli, and Pagano, 2000, for developing countries) find expenditure-led consolidations, especially those focusing on transfers and wage payments, tend to be more persistent and successful in reducing deficits that revenue-driven consolidation, an area where the potential in Kiribati is limited, given its undeveloped private sector. 


\section{Ensuring Implementation}

The framework will require strong ownership and strong budgetary and statistical institutions. This requires greater safeguards on the RERF and a stronger budget processes.

Steps should also be taken to shore up the institutional framework governing the RERF, Kiribati's largest national asset. The principle of holding the wealth of the RERF constant in real terms for future citizens is the lynchpin of the framework. This principle should be given strong legislative backing to ensure that it is effective in anchoring medium-term policies. If politicians and the public are to buy into the strategy of building sizeable savings, they must be informed about the drawdown of RERF assets and the RERF's performance. The government should be required to seek parliamentary approval for all drawdowns of the RERF, and it should report on their implications for sustainability and fiscal policy. Regular and timely reports on the performance of the RERF and how it compares to international benchmarks should also be made public.

Policymakers should also be given incentives to set appropriate budgetary targets. It is key that the budget formulation process be reoriented away from annual targets and towards policies that contribute to the attainment of the medium-term goal. The annual budget should also be cast within a framework of medium-term fiscal forecasts-ideally covering up to 10 years to capture Kiribati’s typical revenue cycle-in order to highlight the long-run implications of policy choices and aid the assessment of revenue trends. It would also be useful to build contingency margins into the budget estimates to ensure that small deviations in macroeconomic performance do not result in budgetary overruns and to require all new spending initiatives to be matched by revenue measures to safeguard deficit targets.

Greater transparency is needed to ensure effective surveillance. This requires frequent, timely, high-quality statistical data on budget implementation. The macroeconomic and policy assumptions underpinning the budget should be made explicit and explained to minimize any tendency toward overly optimistic macroeconomic assumptions. The budget should show how new initiatives and policies impact the annual and medium-term fiscal targets. Timely quarterly reports on budget implementation based on high-quality accounting standards (including for aid and development expenditures) are also essential. However, without donor support, improvements in transparency and data quality could prove difficult, given Kiribati's weak administrative capacity.

Finally, sanctions are needed to correct deviations from the framework's targets. A mid-year review should assess progress towards the targets and the potential impact of changes in the macroeconomic environment. If the review shows that the targets are likely to missed, the government should be required to make additional efforts to limit deviations from the original targets. If subsequent data show the targets were indeed missed, the government should be required to bring the budget back in line with the targets within a set period of time. 


\section{Simulations and Sensitivity Analysis}

A number of simple simulations have been undertaken to illustrate the operation of the fiscal smoothing rule. Utilizing the macroeconomic assumptions in Table 4, the simulations compare how fiscal aggregates evolve over the medium-term using a baseline scenario where there is no smoothing rule and an alternative scenario where the smoothing mechanism is allowed to operate without constraint once fiscal policy has adjusted to a level that is consistent with sustainable use of RERF assets. The main purpose of these simulations is to illustrate how the smoothing mechanism can help manage the volatility in fishing license fees. This requires constructing a hypothetical path for fishing license fees which replicates the movements in acutal fishing license fees observed over the past 10 years (1994-2004). In addition, the simulations can be used to show how sensitive the sustainable level of drawdowns is to changes in the assumption made about the nominal rate of return earned on RERF assets.

The simulations highlight the implication of the sustainability rule for expenditure over the medium term. In both the baseline and alternative scenarios, expenditure trends downward because the target of preserving the real per capita value of the RERF implies that the value of the RERF declines as a share of GDP. As a result, the share of government spending (in relation to GDP) financed by RERF investment income must also decline. This can be justified on intergenerational grounds because if the population is assumed to grow at a lower rate than GDP, this rule permits Kiribati to finance a greater share of its expenditures from the RERF when per capita income levels are low. Targeting a constant expenditure-to-GDP ratio would require that the government save part of the investment income to keep the value of the RERF growing in line with GDP. However, this implies that future generations with higher incomes would get greater use of the RERF, which may not be desirable from an intergenerational perspective.

The simulations show how the smoothing mechanism helps reduce the volatility in the expenditure path. In Figure 7, considerable volatility arises in overall expenditures as spending adjusts with the volatility in fishing license fees when there is no smoothing rule in place. In contrast, the smoothing rule generates a stable expenditure path because the overall deficit is allowed to fluctuate so as to generate the savings necessary to help cushion the level of expenditure when fishing license fees fall below their long-term level.

The simulations also can be used to assess the realism of setting an ex ante cap on the maximum permissible level of the overall deficit. Using the historical year-to-year movements in fishing license fees over a 10-year period and allowing the unbounded operation of the smoothing mechanism reveals only one occasion where the deficit rises substantially above 10 percent of GDP and one where the smoothing mechanism generates budget surpluses. In circumstances where the deficit rises above the upper bound, the government could constrain expenditures to bring the deficit back to the 10 percent ceiling so as not to fully exhaust the 
Figure 7. The Impact of Fiscal Policy Rules in Kiribati (percent of GDP)

\section{Overall Expenditure}
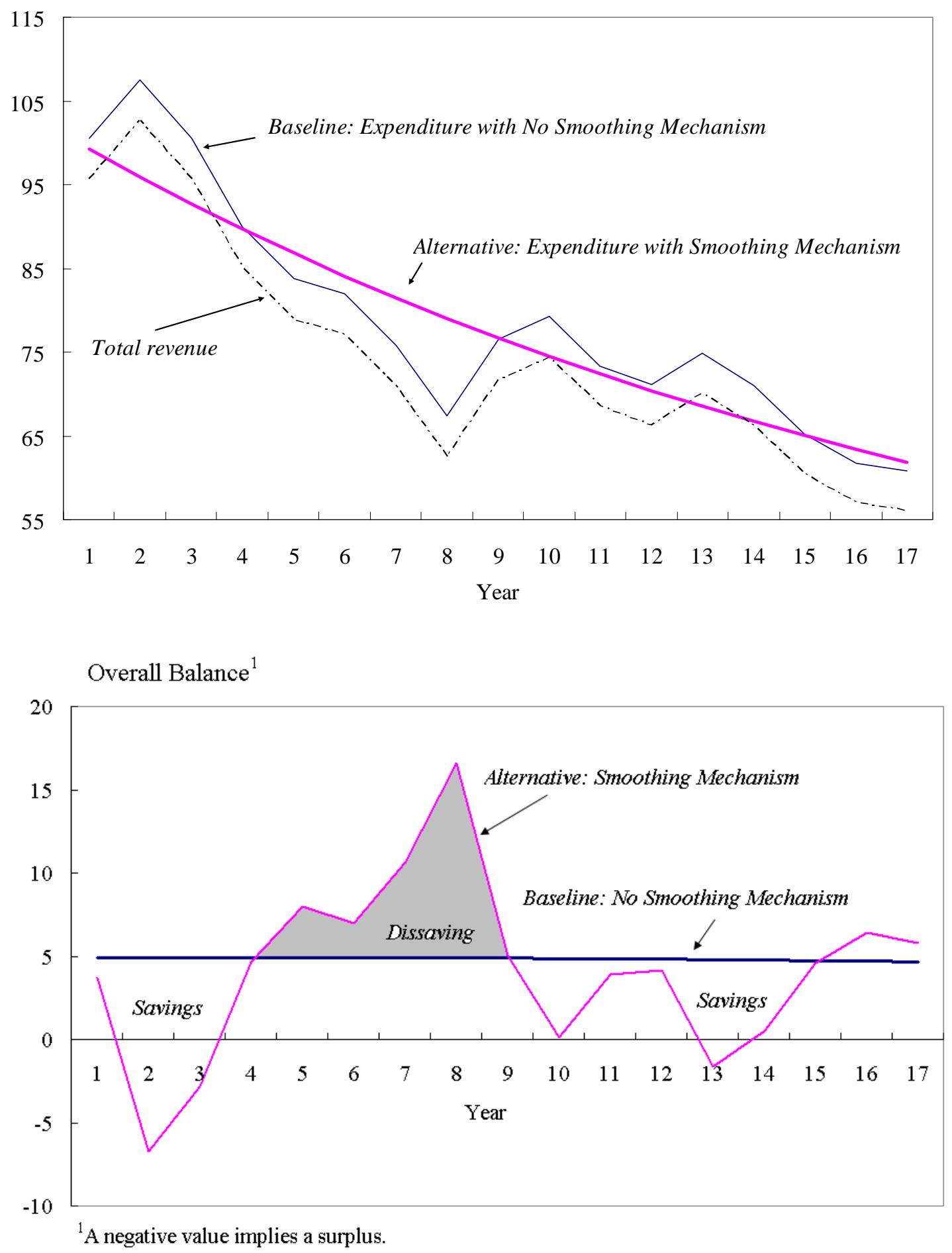
savings cushion. In periods of abnormally high fishing revenues, the government may wish to save the "excess" surplus and not increase expenditures so as to create a large buffer to help cope with periods of abnormally low expenditures.

The sustainable level of RERF drawdown and hence expenditure is also sensitive to the assumptions made about the rate of return on RERF assets. ${ }^{7}$ Figure 8 simulates the sensitivity of these two fiscal variables to a permanent 1 percentage shock to the rate of return when the smoothing mechanism is in place. The results indicate that over the period of the simulation, a permanent 1 percentage point change in the rate of return causes the sustainable level of RERF drawdowns and expenditure to change by an average of about $4 \frac{1}{2}$ percentage points of GDP relative to the baseline case. In reality, the rate of return earned on RERF assets fluctuates widely reflecting global asset market conditions and exchange rate movements, making it difficult for policymakers to distinguish permanent from transitory changes. Countries such as Norway are cautious in their treatment of deviations in the return against the average rate assumed for their fiscal framework (4 percent). Increases in the rate of return above the targeted level are saved, and shortfalls are smoothed out over a number of years.

\section{Conclusion}

Kiribati's fiscal policy should focus on three key goals: (i) Consolidation to restore sustainable policies; (ii) stabilization of the impact of revenue volatility on the budget; and (iii) strengthening the institutional incentives for fiscal discipline to avoid higher spending and deficits in times of plenty.

This paper argues that a rules-based, medium-term fiscal framework provides Kiribati an appropriate compass by which to steer its fiscal ship through its volatile waters. The framework contains-

- $\quad$ A rule that seeks to preserve the real per capita value of the RERF. This rule would seek to link transfers from the RERF to the budget to the realized real per capita rate of return on its assets. The rule determines what constitutes sustainable use of RERF assets, allowing Kiribati to keep its assets safe for future generations.

- $\quad$ A smoothing mechanism that requires the budget to build savings by running surpluses in good times and enabling fiscal policy to better offset the "bad weather" of Kiribati's volatile economic environment.

- $\quad$ Medium-run projections to provide the government a guide as to when and how much it should save and to highlight the trade-offs between spending and saving.

\footnotetext{
${ }^{7}$ The results are also sensitive to the assumptions on population growth and inflation. However, population growth rates only change slowly, and under Kiribati's exchange rate arrangements, inflation is also likley to remain steady at the assumed rate. Changes in the assumptions on GDP growth do not yield large deviations from the baseline simulations.
} 
- $\quad$ A map outlining the direction and magnitude of adjustment needed to reach a sustainable position.

- $\quad$ Strong budgetary institutions and reporting mechanisms to serve as an early-warning system and to provide checks to induce compliance with the framework. 
Figure 8. Simulation of Impact of Change in Rate of Return on Fiscal Rules Framework (percent of GDP)
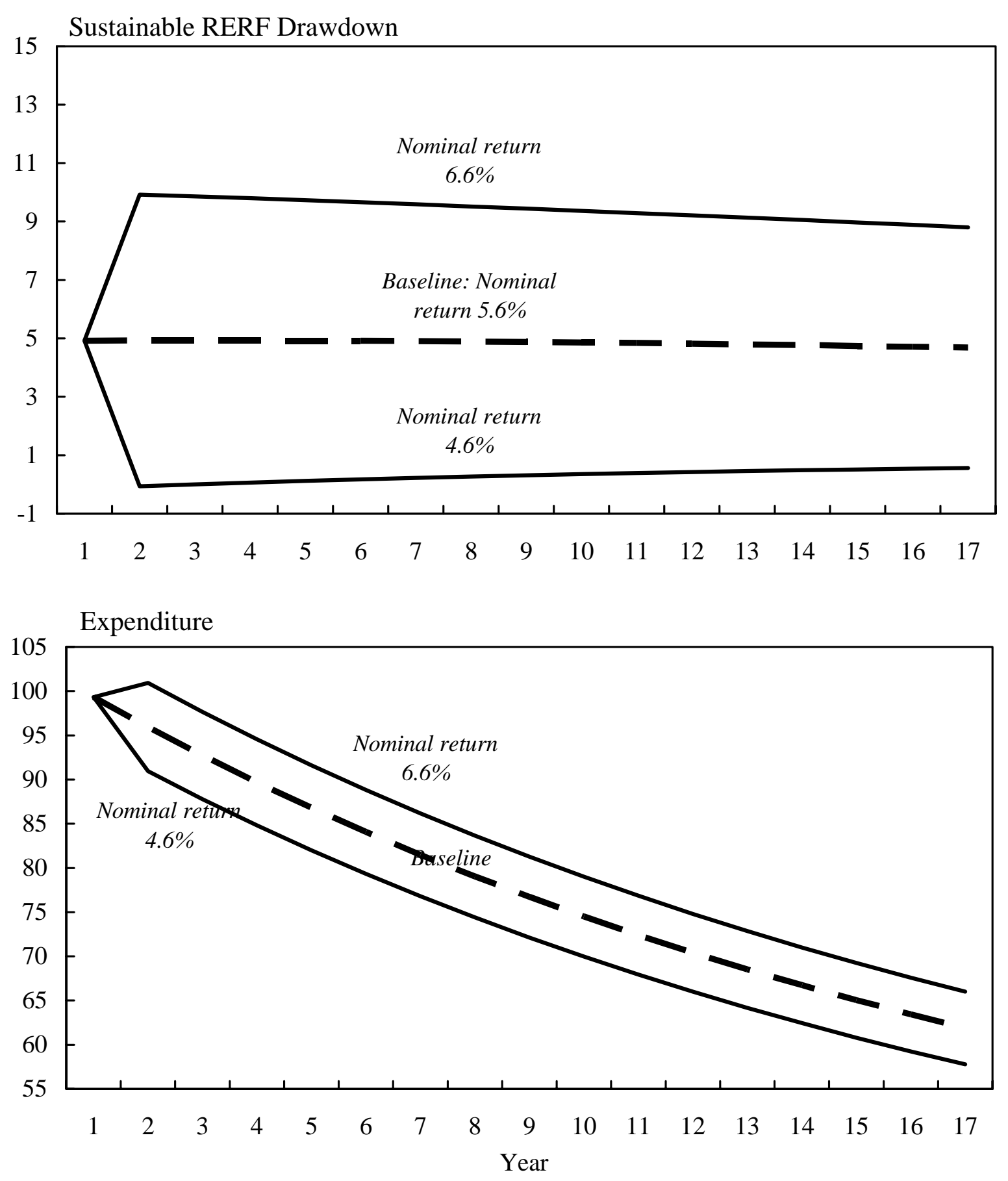

Source: Author estimates. 


\section{References}

Alesina, Alberto, and Roberto Perotti, 1995, "Fiscal Expansions and Adjustments in OECD Countries,” Economic Policy, Vol. 21 (October), pp. 207-48.

Bjerkholt, Olav, and Irene Niculescu, 2004, "Fiscal Rules for Economies with Nonrenewable Resources: Norway and Venezuela,” in Rules Based Fiscal Policy in Emerging Markets, ed. by George Kopits (New York: Palgrave, MacMillian).

Davis, J.M., R. Ossowski, and A. Fedelino, 2003, "Stabilization and Savings Funds for Nonrenewable Resources: Experience and Fiscal Policy Implications,” in Fiscal Policy Formulation and Implementation in Oil-Producing Countries, ed. by J.M. Davis, R. Ossowski, and A. Fedelino (Washington: International Monetary Fund).

Giavazzi, Francesco, Tullio Jappelli, and March Pagano, 2000, "Searching for Non-Linear Effects of Fiscal Policy: Evidence from Industrial and Developing Countries,” NBER Working Paper No. 7460 (Cambridge, Massachusetts: National Bureau of Economic Research).

Kopits, George, and Steven Symansky, 1998, Fiscal Policy Rules, IMF Occasional Paper No. 162 (Washington: International Monetary Fund).

Schuknecht, Ludger, and Vito Tanzi, 2005, "Reforming Public Expenditure in Industrialized Countries: Are there Trade-Offs?” European Central Bank Working Paper Series No. 435 (Frankfurt: European Central Bank).

Shi, Min, 2002, "Fiscal Adjustments in Latin America: Causes, Success and Consequences," University of Wisconsin, unpublished.

Skancke, Martin, 2003, "Fiscal Policy and Petroleum Fund Management in Norway,” in Fiscal Policy Formulation and Implementation in Oil-Producing Countries, ed. by J.M. Davis, R. Ossowski, and A. Fedelino (Washington: International Monetary Fund).

Talvi, Ernesto, and Carlos Végh, 2000, “Tax Base Variability and Procyclical Fiscal Policy,” NBER Working Paper No. 7499 (Cambridge, Massachusetts: National Bureau of Economic Research). 